\title{
Usher syndrome: diagnostic approach, differential diagnoses and proposal of an updated function-based genetic classification
}

https://doi.org/10.1515/medgen-2020-2023

Received March 9, 2020; accepted August 10, 2020

\begin{abstract}
Usher syndrome (USH) manifests with congenital and apparently isolated hearing loss, followed by retinal degeneration in later life. Therefore, and because of its high prevalence in the congenitally hearing-impaired population, USH is one of the most relevant deafness syndromes. Next-generation sequencing (NGS)-based testing can now provide most analyzed USH patients with a molecular diagnosis, based on mutations in 11 genes. Given the availability of several excellent articles on the clinical and biochemical basis of USH, this short review focuses on critical assessment of new genes announced as USH genes, clinical and genetic differential diagnoses and therapeutic developments. Because obsolete loci, disproved USH genes and the inclusion of genes whose mutations cause similar phenotypes have increasingly blurred genetic classification, a revision based on phenotype restricted to genes related to the Usher protein complex is proposed.
\end{abstract}

Keywords: Usher syndrome, retinitis pigmentosa, retinal degeneration, deafness, hearing loss

\section{Genetics and phenotypes of USH}

Usher syndrome (USH) is an autosomal recessive trait currently known to result from mutations in 11 genes. The USH gene loci have numeric and alphabetic designations according to the clinical subtype and the order of their initial descriptions (e. g. USH1B for the MYO7A locus). USH is the underlying diagnosis in approximately $11 \%$ of children with bilateral hearing impairment (often comprehensively termed "deafness"), with a population prevalence of about 1/6000 [1]. Allelic disorders linked to USH gene loci are non-syndromic deafness and (mostly USH2A-related) nonsyndromic retinitis pigmentosa (RP) (and pituitary adenomas, a rather unexpected expression of certain monoal-

\footnotetext{
*Corresponding author: Hanno J. Bolz, Senckenberg Centre for Human Genetics, Weismüllerstr. 50, 60314 Frankfurt am Main, Germany, e-mail: h.bolz@senckenberg-humangenetik.de
}

lelic $\mathrm{CDH} 23$ mutations [2]) (Table 1). USH is characterized by very early - usually congenital - sensorineural hearing loss that may be accompanied by vestibular impairment in USH types 1 and 3 (see below). USH initially manifests as non-syndromic hearing loss. The importance of the USH proteins for retinal photoreceptor cells' function and maintenance is reflected by RP manifesting later in the course of the disorder, with night blindness as the first symptom, followed by progressive concentric constriction of the visual field, ending up as tunnel vision and leaving cone-derived central vision often unaffected. The clinical classification comprises three types, USH1-USH3:

USH1: This is the most severe subtype with profound congenital hearing loss that usually requires cochlear implants (CI), and onset of RP already in the first decade. Vestibular impairment is common, often reflected by delayed achievement of motor milestones - a possible first hint for USH in deaf infants.

USH2: This is the most common (two-thirds of the cases) and mildest clinical subtype. Hearing loss is congenital, stable or slowly progressive and usually does not require $\mathrm{CI}$. RP is diagnosed in puberty or in the early twenties in most cases. There is no vestibular impairment.

USH3: This subtype is very rare in Central Europe, but common in some founder populations (Finland, Québec, Louisiana). Hearing loss is congenital and progressive and may finally require CI supply. Vestibular impairment may occur. Clinical expression of mutations in the USH3 gene, $C L R N 1$, is clinically quite variable and may present with a severe course indistinguishable from USH1.

Atypical USH: Clinical manifestations differing from the above subtypes have been described in patients with pathogenic biallelic variants in USH genes. Atypical USH applies to courses with late onset of either hearing loss or $\mathrm{RP}$, or to unusually severe or mild expression of USH2 and USH1 gene mutations, respectively. The atypical manifestation of USH may be due to different (hypothetical) reasons:

- Atypical USH mutations and genes: Particular mutations and genes are preferentially associated with atypical(ly mild) USH, e. g., the repeatedly reported p.(Asp458Val) variant in USH1G [9, 11], and USH1G mutations in general appear to have a tendency to 
Table 1: The Usher syndrome genes, defined as genes whose mutations cause simultaneous RP and sensorineural deafness and whose gene products interact within the "USH protein complex."

\begin{tabular}{|c|c|c|c|c|c|c|c|}
\hline \multirow{3}{*}{ Gene locus } & \multirow{3}{*}{ Gene } & \multirow{3}{*}{$\%$ of subtype } & \multirow{3}{*}{ Protein (function) } & \multicolumn{4}{|c|}{ Monogenic allelic disorders } \\
\hline & & & & \multicolumn{2}{|c|}{ Deafness } & \multirow{2}{*}{ RP } & \multirow{2}{*}{ Other } \\
\hline & & & & $\overline{\text { ARNSHL }}$ & $\overline{\text { ADNSHL }}$ & & \\
\hline USH1B & MYOTA & $60-70$ & Myosin-7a (motor protein) & DFNB2 & DFNA11 & - & - \\
\hline USH1C & USH1C & $7-10$ & USH1C/Harmonin (scaffold protein) & DFNB18 & Yes [3] & - & \\
\hline USH1D & $\mathrm{CDH} 23$ & $13-16$ & Cadherin-23 (cell adhesion) & DFNB12 & - & - & $\begin{array}{l}\text { Pituitary } \\
\text { adenomas } \\
\text { (a.d.) [2] }\end{array}$ \\
\hline USH1F & PCDH15 & $5-8$ & Protocadherin-15 (cell adhesion) & DFNB23 & - & - & - \\
\hline USH1G & USH1G & $2-3$ & USH1G/SANS (scaffold protein) & Yes [4] & - & - & - \\
\hline USH1M [5] & $E S P N$ & $<1$ & Espin (actin-bundling) & DFNB36 & Yes [6] & - & - \\
\hline USH $2 A$ & USH $2 A$ & $\geq 90$ & USH2A/Usherin (cell adhesion) & Yes [7] & - & & - \\
\hline USH $2 C$ & $A D G R V 1$ & $5-8$ & $\begin{array}{l}\text { Adhesion G protein-coupled receptor } \\
\text { V1 (cell-surface calcium-binding GPCR) }\end{array}$ & - & - & Yes [8] & - \\
\hline USH2D & WHRN & $<1$ & $\begin{array}{l}\text { Cask-interacting protein } 98, \text { whirlin } \\
\text { (scaffold protein) }\end{array}$ & DFNB31 & - & - & - \\
\hline USH $3 A$ & CLRN1 & $\begin{array}{r}\text { Region- } \\
\text { dependent }\end{array}$ & $\begin{array}{l}\text { Clarin-1 (hair bundle protein, function } \\
\text { largely unknown) }\end{array}$ & - & - & $R P 61$ & - \\
\hline Digenic USH2 & USH2C-PDZD7 & $<1$ & $\begin{array}{l}\text { ADGRV1 and PDZ domain-containing } 7 \\
\text { (scaffold protein) }\end{array}$ & DFNB57 & - & - & - \\
\hline
\end{tabular}

RP, retinitis pigmentosa. Indicated prevalences of mutations in a gene for clinical subtypes are approximate values, deduced from large NGS studies $[9,10]$, and do not take into account the predominant role of the otherwise rare genes CLRN1 (USH3A) and USH1C in populations like those in Finland, Louisiana or Québec.

ARNSHL, autosomal recessive non-syndromic hearing loss.

ADNSHL, autosomal dominant non-syndromic hearing loss.

$\mathrm{RP}$, retinitis pigmentosa.

a. d., autosomal dominant.

GPCR, G protein-coupled receptor. References are given for less known allelic disorders that have no locus names yet, for alleles which are underrepresented in reviews on USH genes and for USH1M, a recently described USH locus.

manifest as atypical USH: Four individuals with a homozygous frameshift mutation have been described with unexpectedly mild USH2-like phenotype [12] while other patients with such USH1G mutations express USH1 [9]. A modification of the phenotype by genetic or epigenetic factors could account for this USH1G phenomenon (see next paragraph).

- Modifiers: We have reported two sisters with biallelic USH2A mutations and divergent phenotypes. The assumption that the atypically severe retinal phenotype in one of them is due to heterozygosity for a frameshift mutation in PDZD7, encoding a member of the USH protein complex, was supported by experimental animal data [13]. Little else is currently known about the identity of genetic modifiers of USH.

- Borderline mutations: In our diagnostic cohort, a female patient with compound-heterozygous MYO7A mutations (c.287C >T (p.(Thr96Met)) and c.1189G $>$ A (p.(Ala397Thr))) had early progressive hearing loss, but late onset of vestibular impairment (30 years) and night blindness (33 years). Both mutations had previously been reported in conjunction with autosomal recessive non-syndromic hearing loss (ARNSHL) and USH [14, 15]. They could be "too weak" to cause USH1B, with late manifestation of symptoms beyond non-syndromic DFNB2.

- Age-dependent penetrance: USH2A mutations cause either USH2 or non-syndromic RP, RP25 [16]. Analyses of Ush2a-null mice indicate that the USH2A protein is required for maintenance of retinal photoreceptors and normal development of cochlear hair cells [17]. An RP patient from our clinic with heterozygosity for USH2A variants c.908G $>$ A (p.(Arg303His)) and c.6223T $>\mathrm{C}$ (p.(Trp2075Arg)) was diagnosed with bilateral sensorineural hearing loss affecting the high frequencies, requiring hearing aids, at the age of 64 years. Family history for hearing impairment was negative, and no mutations were found in deafness genes. Her USH2A mutations may be primarily RP mutations that - in contrast to full USH2 mutations and the biallelic gene inactivation in the mouse model [17] - affect maintenance of hair cells after a lifetime exposure 
Table 2: Additional gene loci proposed for Usher syndrome based on genes functionally unrelated to the originary Usher genes.

\begin{tabular}{lllll}
\hline Gene & Disease & $\begin{array}{l}\text { Assigned Usher syndrome } \\
\text { type }\end{array}$ & Pathomechanism, protein & Distinctive symptoms \\
\hline HARS1 & CMT2W (a.d.) & “USH3B” & Histidyl-tRNA synthetase & $\begin{array}{l}\text { Visual hallucinations, } \\
\text { psychosis }\end{array}$ \\
ARSG & $\begin{array}{l}\text { Neuronal ceroid lipofuscinosis (NCL) } \\
\text { in dogs, MPS IIIE (with retinal } \\
\text { degeneration) in mice }\end{array}$ & $\begin{array}{l}\text { “USH4” (atypical Usher } \\
\text { syndrome) }\end{array}$ & Arylsulfatase G & $\begin{array}{l}\text { Macular involvement, late } \\
\text { onset of HL (>40 years) }\end{array}$ \\
\hline
\end{tabular}

MPS, mucopolysaccharidosis.

$\mathrm{HL}$, hearing loss.

a. d., autosomal dominant.

to environmental influences (including noise), causing late transition to dual sensory impairment. A similar phenotypic constellation has been described in patients from two Yemenite Jewish families with a homozygous founder frameshift mutation in an alternative USH1C exon and late-onset hearing loss [18].

\section{Proposal of a strict genetic classification based on phenotype and protein function}

Over the recent years, additional loci and genes have been proposed as USH-associated, with different levels of evidence. To avoid further blurring of the USH gene nomenclature, I propose an update of the list of USH genes and loci, following strict criteria for inclusion and exclusion: Inclusion:

- USH protein network members: The products of the originary USH genes interact within large multiprotein complexes with important functions in cochlear hair cells and retinal photoreceptor cells [19-21]. Consequently, USH1M, a recently proposed novel locus linked to biallelic ESPN mutations causing an USH1 phenotype with vestibular impairment, should be contained in USH gene lists claiming up-todateness [5].

\section{Exclusion:}

- Removal of obsolete loci: USH1A, USH1E, USH1H, $U S H 1 K$, and $U S H 2 B$ have either been retracted as USH loci or have not been proven to contain USH genes. They should be removed from the USH genetics nomenclature.

- Removal of questionable genes: HARS1 has been proposed as a novel USH3 gene in a single family (USH3B,
OMIM \#614504) [22]. Because of additional homozygous variants in the index patient, additional symptoms and the high frequency of the mutant allele in the Amish population, there is limited evidence that this is really an USH gene (Table 2). CIB2 mutations are a regionally highly prevalent cause of ARNSHL, but probably do not cause USH1 (USH1J, OMIM \#614869) [23].

- No introduction of novel clinical USH subtypes: While the causality of the homozygous founder missense variant c.133G $>\mathrm{T}$ (p.(Asp45Tyr)) in arylsulfatase $\mathrm{G}$ $(A R S G)$ for retinal degeneration and hearing loss in the reported families is plausible, the phenotype does not fit the subtypes USH1-3 [24]. Creation of a novel clinical subtype, USH4 (OMIM \#618144), for a protein that in addition is probably functionally unrelated to the known USH proteins, does not seem appropriate (Table 2).

\section{Molecular diagnostics in Usher syndrome}

NGS has dramatically increased the diagnostic yield for patients with USH. Among the many genetically heterogeneous disorders, USH is an outstanding example that demonstrates how NGS has revolutionized genetic diagnostics: Today, almost every USH patient can get a genetic diagnosis (provided the health insurance covers the costs), with detection rates of around or above $90 \%$ reported in comprehensive NGS studies [9, 10, 25] (Table 1). In contrast to non-syndromic RP or deafness, with probably many more rare genes to be discovered that account for the $\geq 30 \%$ of cases that remain mutation-negative after comprehensive NGS panel analysis, the genes for USH have essentially been found. If more USH genes should be found, their mutations would account for a very small fraction of patients only. The subsequent paragraphs thus 
address possible reasons why no mutations are found in some patients with apparent USH despite NGS of the known USH genes (Table 1), falling into two groups - in the order of likelihood (personal assumption):

1. The true diagnosis is not USH.

2. One or both mutations in an USH gene have escaped detection (misinterpretation, quality issues, deep intronic mutations).

Awareness of such alternative explanations may help to fill those diagnostic gaps.

\section{Dead angles: "Difficult" mutations in USH genes}

Copy number variations (CNVs) affecting one or several exons contribute significantly to USH $[9,10]$. They represent a diagnostic challenge, but - due to improved bioinformatics for quantitative readout of NGS data - to a lesser extent than some years ago.

Several deep-intronic mutations have been identified in USH patients [26-28]. For USH2A, Roux and coworkers have established an approach comprising genomic sequencing (including the introns), bioinformatic analysis focused on effects like pseudo-exon formation and subsequent minigene analysis to evaluate the variants' effects on splicing. While genomic sequencing of the USH genes (at least of those associated with the majority of cases: USH2A, MYO7A and CDH23) is manageable for specialized diagnostic institutions, analysis of the effect on splicing (either on RNA from blood or tissue or by a minigene assay) is beyond the scope of most labs and not covered by reimbursements provided by the health insurances. RNAseq represents an attractive NGS application that could help to uncover USH gene variants that impact splicing or gene expression $[29,30]$. While it is relatively unlikely that both alleles carry "hidden mutations" (CNVs, deep-intronic) in patients with unrelated parents, this has to be taken into account in offspring from consanguineous partners because one such variant segregating in the family is sufficient [26].

\section{False mutations}

Truncating variants in the USH1F gene, $P C D H 15$, which affect the cytoplasmic domain of the protein, may be tolerated, possibly due to several alternate cytoplasmic do- main exons and differentially spliced isoforms of redundant function [31]. A similar phenomenon is known for two other genes associated with both isolated and syndromic retinopathy, RP1 and AHI1 [32-34]. The awareness that truncating variants in non-disease-related - "dispensable" - gene regions can be disregarded is crucial to avoid diagnostic pitfalls.

\section{Other conditions mimicking USH}

If bilateral hearing impairment and retinal degeneration are both present in a patient, USH is the likely, but not the only possible diagnosis. Detailed phenotyping, not only of the sensory deficits, and careful assessment of the medical and family history are important, but not always possible. The real condition may only be unmasked after comprehensive NGS analysis ("reverse phenotyping").

"Usher-plus" - probably another disease: Symptoms beyond deaf-blindness may indicate other (genetic) diagnoses (Table 3, Figure 1). Rare abnormalities like enamel dysplasia, for example, should prompt analysis of peroxisome biogenesis disorder (PBD) genes from the Refsum syndrome/Zellweger disease spectrum [9, 35, 36]. NGS allows for testing of many more genes than the USH genes, and including genes whose mutations cause similar phenotypes may provide the diagnosis quickly in "pseudoUSH patients" - based on the initial NGS dataset (Figure 1). In patients with PBD gene mutations and phenotypes resembling USH (reported for biallelic mutations in PEX1, PEX6 and PEX26 so far), specific prophylactic measures can be taken. Such patients (who may in early childhood present with little else than deafness) should be monitored for hepatopathy, elevation of fatty acids and, of course, retinopathy: Such patients should avoid certain medications and hepatotoxic substances. In contrast to USH, patients with mild PBD may benefit from phytanic acid-restricted diet and extracorporeal lipid apheresis [37-39].

Two diseases in one patient: Simultaneous affliction with non-syndromic RP and deafness may mimic USH. Because RP and inherited deafness are both relatively "common" among the rare diseases, such co-occurrence does happen. Consanguineous partnerships are particularly prone to such constellations in the offspring [54], so they must be taken into account. Unless the non-syndromic phenotypes dissociate among siblings, detailed phenotyping especially of the retinal phenotype is the only other possibility to distinguish between USH and two diseases. We reported two families/patients initially referred to us 


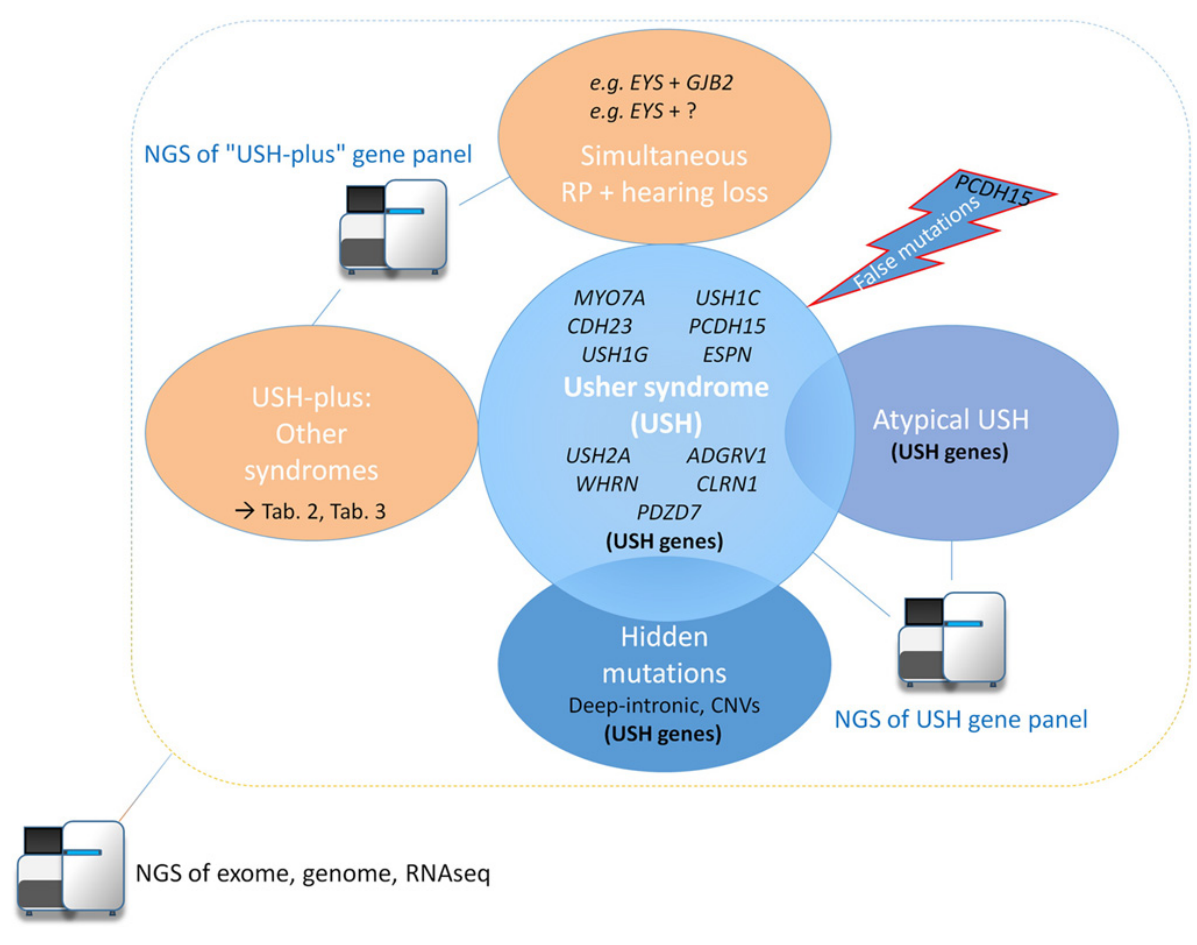

Figure 1: Usher syndrome, its differential diagnoses and the genetic methodology to uncover them.

as having Usher syndrome in whom we found simultaneous mutations in DFNB59/MERTK [55] and OTOA/NR2E3 [9], respectively. Retrospectively, the patients in these families had retinopathies distinct from RP. Thus, clinical misclassification could have been avoided in the first place.

$R P$ with non-genetic hearing loss: While RP can generally be considered a monogenic entity (except from atypical presentations, e.g., unilateral RP, likely representing phenocopies caused by non-genetic factors [56]), nongenetic factors contribute significantly to early hearing impairment: Congenital cytomegalovirus infections, for example, account for $\sim 10 \%$ and $15-20 \%$ of congenital and childhood deafness, respectively $[57,58]$. We have identified two splice site mutations in one of the most prevalent autosomal recessive non-syndromic RP genes, EYS, in a patient with additional hearing loss, but not his cause of deafness. This and similar patients with EYS-related RP and unexplained deafness [59] possibly reflect coincidence of non-syndromic RP and acquired deafness.

\section{Therapy}

Hearing deficits can be treated by hearing aids or, in USH1 and USH3, by CI (that said, the development of cochlear gene therapy approaches has made remarkable progress in the recent years [60]). USH-related retinal degeneration represents the main problem because no curative therapy is currently available. However, development of several therapeutic strategies is underway in different places [61]. For any therapy aimed at preventing retinal degeneration in USH, patients must be identified early and before widespread irreversible photoreceptor loss has occurred. From this point of view, the congenital hearing loss in USH represents a potential advantage: While non-syndromic $\mathrm{RP}$ is usually diagnosed only at an advanced stage, consequent comprehensive NGS-based diagnostics can easily identify the $\geq 10 \%$ with USH gene mutations among the congenitally hearing-impaired children many years before the onset of RP. Every newborn with unexplained congenital bilateral sensorineural deafness should hence receive NGS testing; unfortunately, the reality is currently far from that, and constant efforts are necessary to make pediatricians and otorhinolaryngologists aware of this. USH patients could today almost entirely be identified before onset of retinal degeneration - when they would particularly benefit from gene therapy.

The subsequent examples for USH therapy strategies do not claim completeness but give insight into different approaches (for review, regarding both the hearing and the visual impairment, see reference [62]).

Gene therapy: The eye is easily accessible and immune-privileged and hence an ideal organ for gene 
Table 3: Examples of gene loci associated with phenotypes that may resemble Usher syndrome.

\begin{tabular}{|c|c|c|c|c|c|}
\hline Gene & Disease & $\begin{array}{l}\text { Similar } \\
\text { to/reported as }\end{array}$ & Pathomechanism, protein & Distinctive symptoms & References \\
\hline PEX1 & Heimler syndrome & USH1 & Peroxisome biogenesis disorder & $\begin{array}{l}\text { Enamel dysplasia, nail } \\
\text { abnormalities }\end{array}$ & {$[35]$} \\
\hline PEX6 & Heimler syndrome & USH1 & Peroxisome biogenesis disorder & $\begin{array}{l}\text { Microcephaly, ID, enamel } \\
\text { dysplasia, nail abnormalities }\end{array}$ & {$[35,36]$} \\
\hline PEX26 & Heimler syndrome & USH1 & Peroxisome biogenesis disorder & $\begin{array}{l}\text { Enamel dysplasia, hepatopathy, } \\
\text { retinitis punctata albescens with } \\
\text { macular involvement }\end{array}$ & [9] \\
\hline$A B H D 12$ & PHARC & USH3-like & $\begin{array}{l}\text { ABHD12 hydrolyzes } \\
\text { 2-arachidonoyl glycerol, an } \\
\text { endocannabinoid lipid } \\
\text { transmitter (acts on } \\
\text { cannabinoid } \\
\text { receptors CB1 and CB2) }\end{array}$ & Polyneuropathy, ataxia, cataract & {$[40]$} \\
\hline CEP78 & $\begin{array}{l}\text { Cone-rod degeneration, } \\
\text { sensorineural hearing } \\
\text { loss }\end{array}$ & Atypical USH & Retinal ciliopathy & $\begin{array}{l}\text { Cone photoreceptors primarily } \\
\text { affected, postlingual onset of } \mathrm{HL}\end{array}$ & {$[41-43]$} \\
\hline CEP250 & $\begin{array}{l}\text { RP, non-syndromic or } \\
\text { with } \mathrm{HL} \text {; cone-rod } \\
\text { dystrophy with hearing } \\
\text { loss }\end{array}$ & Atypical USH & Retinal ciliopathy & $\begin{array}{l}\text { May be hard to differentiate. } \\
\text { Cone-rod dystrophy appears to } \\
\text { be more common than RP }\end{array}$ & [44-46] \\
\hline EXOSC2 & $\begin{array}{l}\text { Premature ageing } \\
\text { syndrome }\end{array}$ & USH3-like & $\begin{array}{l}\text { Core component of the RNA } \\
\text { exosome }\end{array}$ & $\begin{array}{l}\text { Premature ageing, short stature, } \\
\text { ID, dysmorphism }\end{array}$ & {$[47]$} \\
\hline PLD4 & $\begin{array}{l}\text { No other disease } \\
\text { associations }\end{array}$ & Usher syndrome & $\begin{array}{l}\text { Phospholipase, acid } \\
\text { exonuclease, regulates } \\
\text { endosomal nucleic-acid sensing }\end{array}$ & n.d. & [48] \\
\hline TUBB $4 B$ & LCA, early HL & Syndromic LCA & Abnormal MT growth & LCA instead of RP & [49] \\
\hline$R P G R$ & X-linked RP (RP3) & $\mathrm{RP}$ and $\mathrm{HL}$ & Retinal ciliopathy & $\begin{array}{l}\text { X-linked inheritance, retinal } \\
\text { abnormalities in female carriers }\end{array}$ & {$[50]$} \\
\hline MTTS2 & $\mathrm{RP}$, progressive $\mathrm{HL}$ & USH3-like & Mitochondrial disease & $\begin{array}{l}\text { Subclinical muscle } \\
\text { abnormalities, mitochondrial } \\
\text { inheritance }\end{array}$ & {$[51]$} \\
\hline YARS1 & HL, retinal dystrophy & Atypical USH & $\begin{array}{l}\text { tyrosyl-tRNA synthetase, critical } \\
\text { for protein translation }\end{array}$ & $\begin{array}{l}\text { May manifest as multisystem } \\
\text { disorder with ID and growth } \\
\text { delay, brain dysmyelination, } \\
\text { microcephaly, agenesis of } \\
\text { corpus callosum, liver and } \\
\text { pancreatic disease, etc. }\end{array}$ & {$[52,53]$} \\
\hline
\end{tabular}

RP, retinitis pigmentosa.

$\mathrm{HL}$, hearing loss.

ID, intellectual disability.

LCA, Leber congenital amaurosis.

MT, microtubule.

PHARC, polyneuropathy, hearing loss, ataxia, retinitis pigmentosa and cataract.

therapy. Given the encouraging example of gene therapy for RPE65-associated recessively inherited retinal dystrophies, such gene replacement approaches probably represent realistic options for effective treatment of USH. The enormous size of most USH genes, including the most commonly mutated (encoded amino acid residues in USH2C: $>6,000$; USH2A: >5,000; USH1D: >3,000; USH1B: >2,000; USH1F: almost 2,000), is a major hurdle for packaging into adeno-associated virus (AAV). The delivery of multiple AAV vectors each containing a fragment of the gene flanked by short split inteins resulting in trans-splicing and full-length protein is currently investigated as a potential method to overcome the oversize gene problem [63], while genome editing of DNA or RNA is pursued as an AAV-independent method [64, 65]. Successful gene therapy has been demonstrated in mouse models for USH1B 
[66], USH1C [67] and USH3A [68]. Because retinal degeneration in USH mouse models is absent or does not correspond to the human RP phenotype, the readout for therapy in USH mouse models is the inner ear/cochlear function in most cases. An overall problematic issue for gene therapy is the existence of multiple isoforms for every USH gene, with limited current knowledge regarding the importance of every isoform for retinal function [61].

Antisense oligonucleotides (ASOs): ASOs are particularly useful for targeting mutations resulting in mis-splicing, and especially those contributing significantly to the mutational load. Both are the case for the c.216G $>\mathrm{A}_{U S H 1 C}$ mutation, the predominant diseasecausing variant in USH1 patients from Louisiana and Québec, and ASO treatment of neonatal mice was able to rescue hearing and vestibular function [69]. For a recurrent deep-intronic USH2A mutation, ASO-mediated correction of impaired splicing was possible in patients' cells and in a minigene splice assay [70].

Compounds: Phenotypic high-throughput screening assays with medicinal chemistry identified BF844, a small molecule that stabilizes plasma membrane expression of p.(Asn48Lys) (N48K)-mutated CLRN1 (USH3A) and thereby prevents its degradation [71]. The compound was able to attenuate progressive deafness in an $\mathrm{N} 88 \mathrm{~K}_{C L R N 1}$ mouse model. CLRN1 ${ }_{\mathrm{N} 48 \mathrm{~K}}$ largely fails to reach its predestined localization in the cochlear hair bundle due to its aggregation in the endoplasmic reticulum. In another study, the small amount of mutant CLRN1 that does reach the hair bundle was found to do so by an unconventional secretory pathway. This pathway could be activated by the antimalarial drug artemisinin, resulting in enhanced $\mathrm{CLRN1}_{\mathrm{N} 48 \mathrm{~K}}$ levels in hair cell bundles with rescued functions [72].

\section{Conclusions}

In summary, there has been tremendous progress in research on the causes of USH, its biochemical basis, and different avenues towards therapy in patients who can be treated prior to the onset of RD. Paramount is the early identification of USH patients among the congenitally hearing-impaired children, and comprehensive genetic analysis must thus become routine after failed newborn hearing screening.

\section{Sources of information for patients and physicians}

More information can be found on the websites of PRO RETINA (https://www.pro-retina.de/ netzhauterkrankungen/usher-syndrom), Leben mit Usher-Syndrom e. V. (https://www.leben-mit-usher.de) and Usher Syndrome Coalition (https://www.ushersyndrome.org). The German Society of Human Genetics will provide information about institutes specialized in hereditary sensory disorders (diagnostics, genetic counseling and research), including USH, on their website (https://www.gfhev.de).

Conflict of interest: The author declares that he has no competing interests.

\section{References}

[1] Kimberling WJ, Hildebrand MS, Shearer AE, Jensen ML, Halder JA, Trzupek K, et al Frequency of Usher syndrome in two pediatric populations: Implications for genetic screening of deaf and hard of hearing children. Genet Med. 2010;12:512-6.

[2] Zhang Q, Peng C, Song J, Zhang Y, Chen J, Song Z, et al Germline Mutations in $\mathrm{CDH} 23$, Encoding Cadherin-Related 23, Are Associated with Both Familial and Sporadic Pituitary Adenomas. Am J Hum Genet. 2017;100:817-23.

[3] Song JS, Bahloul A, Petit C, Kim SJ, Moon IJ, Lee J, Ki CS. A Novel Heterozygous Missense Variant (c. 667G>T; p.Gly223Cys) in USH1C That Interferes With Cadherin-Related 23 and Harmonin Interaction Causes Autosomal Dominant Nonsyndromic Hearing Loss. Ann Lab Med. 2020;40:224-31.

[4] Maria Oonk AM, van Huet RA, Leijendeckers JM, Oostrik J, Venselaar $\mathrm{H}$, van Wijk $\mathrm{E}$, et al Nonsyndromic hearing loss caused by USH1G mutations: widening the USH1G disease spectrum. Ear Hear. 2015;36:205-11.

[5] Ahmed ZM, Jaworek TJ, Sarangdhar GN, Zheng L, Gul K, Khan $\mathrm{SN}$, et al Inframe deletion of human ESPN is associated with deafness, vestibulopathy and vision impairment. J Med Genet. 2018;55:479-88.

[6] Donaudy F, Zheng L, Ficarella R, Ballana E, Carella M, Melchionda S, et al Espin gene (ESPN) mutations associated with autosomal dominant hearing loss cause defects in microvillar elongation or organisation. J Med Genet. 2006;43:157-61.

[7] Lenassi E, Robson AG, Luxon LM, Bitner-Glindzicz M, Webster AR. Clinical heterogeneity in a family with mutations in USH2A. JAMA Ophthalmol. 2015;133:352-5.

[8] Wang F, Wang H, Tuan HF, Nguyen DH, Sun V, Keser $V$, et al Next generation sequencing-based molecular diagnosis of retinitis pigmentosa: identification of a novel genotype-phenotype correlation and clinical refinements. Hum Genet. 2014;133:331-45. 
[9] Neuhaus C, Eisenberger T, Decker C, Nagl S, Blank C, Pfister $M$, et al Next-generation sequencing reveals the mutational landscape of clinically diagnosed Usher syndrome: copy number variations, phenocopies, a predominant target for translational read-through, and PEX26 mutated in Heimler syndrome. Mol Genet Genomic Med. 2017;5:531-52.

[10] Bonnet C, Riahi Z, Chantot-Bastaraud S, Smagghe L, Letexier $M$, Marcaillou $C$, et al An innovative strategy for the molecular diagnosis of Usher syndrome identifies causal biallelic mutations in $93 \%$ of European patients. European journal of human genetics. Eur J Hum Genet. 2016;24:1730-8.

[11] Kalay E, de Brouwer AP, Caylan R, Nabuurs SB, Wollnik B, Karaguzel A, et al A novel D458V mutation in the SANS PDZ binding motif causes atypical Usher syndrome. J Mol Med. 2005;83:1025-32.

[12] Bashir R, Fatima A, Naz S. A frameshift mutation in SANS results in atypical Usher syndrome. Clin Genet. 2010;78:601-3.

[13] Ebermann I, Phillips JB, Liebau MC, Koenekoop RK, Schermer B, Lopez I, et al PDZD7 is a modifier of retinal disease and a contributor to digenic Usher syndrome. J Clin Invest. 2010;120:1812-23.

[14] Rudman JR, Kabahuma RI, Bressler SE, Feng Y, Blanton SH, Yan D, Liu XZ. The genetic basis of deafness in populations of African descent. J Genet Genomics. 2017;44:285-94.

[15] Yan D, Tekin D, Bademci G, Foster J 2nd, Cengiz FB, Kannan-Sundhari A, et al Spectrum of DNA variants for non-syndromic deafness in a large cohort from multiple continents. Hum Genet. 2016;135:953-61.

[16] Pierrache LH, Hartel BP, van Wijk E, Meester-Smoor $M A$, Cremers FP, de Baere E, et al Visual Prognosis in USH2A-Associated Retinitis Pigmentosa Is Worse for Patients with Usher Syndrome Type Ila Than for Those with Nonsyndromic Retinitis Pigmentosa. Ophthalmology. 2016;123:1151-60.

[17] Liu X, Bulgakov OV, Darrow KN, Pawlyk B, Adamian M, Liberman MC, Li T. Usherin is required for maintenance of retinal photoreceptors and normal development of cochlear hair cells. Proc Natl Acad Sci USA. 2007;104:4413-8.

[18] Khateb S, Zelinger L, Ben-Yosef T, Merin S, Crystal-Shalit 0 , Gross $M$, et al Exome sequencing identifies a founder frameshift mutation in an alternative exon of USH1C as the cause of autosomal recessive retinitis pigmentosa with late-onset hearing loss. PLoS ONE. 2012;7:e51566.

[19] Mathur P, Yang J. Usher syndrome: Hearing loss, retinal degeneration and associated abnormalities. Biochim Biophys Acta. 2015;1852:406-20.

[20] Schietroma C, Parain K, Estivalet A, Aghaie A, Boutet de Monvel J, Picaud S, et al Usher syndrome type 1-associated cadherins shape the photoreceptor outer segment. J Cell Biol. 2017;216:1849-64.

[21] Richardson GP, Petit C. Hair-Bundle Links: Genetics as the Gateway to Function. Cold Spring Harb Perspect Med. 2019;9.

[22] Puffenberger EG, Jinks RN, Sougnez C, Cibulskis K, Willert RA, Achilly NP, et al Genetic mapping and exome sequencing identify variants associated with five novel diseases. PLoS ONE. 2012;7:e28936.

[23] Booth KT, Kahrizi K, Babanejad M, Daghagh H, Bademci G, Arzhangi S, et al Variants in CIB2 cause DFNB48 and not USH1J. Clin Genet. 2018;93:812-21.
[24] Khateb S, Kowalewski B, Bedoni N, Damme M, Pollack $\mathrm{N}$, Saada A, et al A homozygous founder missense variant in arylsulfatase $\mathrm{G}$ abolishes its enzymatic activity causing atypical Usher syndrome in humans. Genet Med. 2018;20:1004-12.

[25] Besnard T, Garcia-Garcia G, Baux D, Vache C, Faugere V, Larrieu $L$, et al Experience of targeted Usher exome sequencing as a clinical test. Mol Genet Genomic Med. 2014;2:30-43.

[26] Khan AO, Becirovic E, Betz C, Neuhaus C, Altmuller J, Maria Riedmayr L, et al A deep intronic CLRN1 (USH3A) founder mutation generates an aberrant exon and underlies severe Usher syndrome on the Arabian Peninsula. Sci Rep. 2017;7:1411.

[27] Liquori A, Vache C, Baux D, Blanchet C, Hamel C, Malcolm S, et al Whole USH2A Gene Sequencing Identifies Several New Deep Intronic Mutations. Human Mutat. 2016;37:184-93.

[28] Vache C, Besnard T, le Berre P, Garcia-Garcia G, Baux D, Larrieu $L$, et al Usher syndrome type 2 caused by activation of an USH2A pseudoexon: implications for diagnosis and therapy. Human Mutat. 2012;33:104-8.

[29] Lee H, Huang AY, Wang LK, Yoon AJ, Renteria G, Eskin A, et al Diagnostic utility of transcriptome sequencing for rare Mendelian diseases. Genet Med. 2020;22:490-9.

[30] Gonorazky HD, Naumenko S, Ramani AK, Nelakuditi V, Mashouri P, Wang P, et al Expanding the Boundaries of RNA Sequencing as a Diagnostic Tool for Rare Mendelian Disease. Am J Hum Genet. 2019;104:1007.

[31] Perreault-Micale C, Frieden A, Kennedy CJ, Neitzel D, Sullivan J, Faulkner N, et al Truncating variants in the majority of the cytoplasmic domain of PCDH15 are unlikely to cause Usher syndrome 1F. J Mol Diagnostics. 2014;16:673-8.

[32] Chen LJ, Lai TY, Tam PO, Chiang SW, Zhang X, Lam S, et al Compound heterozygosity of two novel truncation mutations in RP1 causing autosomal recessive retinitis pigmentosa. Investig Ophthalmol Vis Sci. 2010;51:2236-42.

[33] Eisenberger T, Neuhaus C, Khan AO, Decker C, Preising $M N$, Friedburg C, et al Increasing the yield in targeted next-generation sequencing by implicating CNV analysis, non-coding exons and the overall variant load: the example of retinal dystrophies. PLoS ONE. 2013;8:e78496.

[34] Elsayed SM, Phillips JB, Heller R, Thoenes M, Elsobky E, Nurnberg G, et al Non-manifesting AHI1 truncations indicate localized loss-of-function tolerance in a severe Mendelian disease gene. Hum Mol Genet. 2015;24:2594-603.

[35] Ratbi I, Falkenberg KD, Sommen M, Al-Sheqaih N, Guaoua $S$, Vandeweyer G, et al Heimler Syndrome Is Caused by Hypomorphic Mutations in the Peroxisome-Biogenesis Genes PEX1 and PEX6. Am J Hum Genet. 2015;97:535-45.

[36] Zaki MS, Heller R, Thoenes M, Nurnberg G, Stern-Schneider G, Nurnberg P, et al PEX6 is Expressed in Photoreceptor Cilia and Mutated in Deafblindness with Enamel Dysplasia and Microcephaly. Human Mutat. 2016;37:170-4.

[37] Baldwin EJ, Gibberd FB, Harley C, Sidey MC, Feher MD, Wierzbicki AS. The effectiveness of long-term dietary therapy in the treatment of adult Refsum disease. J Neurol Neurosurg Psychiatry. 2010;81:954-7.

[38] Baldwin EJ, Harrington DJ, Sampson B, Feher MD, Wierzbicki AS. Safety of long-term restrictive diets for peroxisomal disorders: vitamin and trace element status of patients treated for Adult Refsum Disease. Int J Clin Pract. 2016;70:229-35. 
[39] Ruether K, Baldwin E, Casteels M, Feher MD, Horn M, Kuranoff $S$, et al Adult Refsum disease: a form of tapetoretinal dystrophy accessible to therapy. Surv Ophthalmol. 2010;55:531-8.

[40] Eisenberger T, Slim R, Mansour A, Nauck M, Nurnberg G, Nurnberg $P$, et al Targeted next-generation sequencing identifies a homozygous nonsense mutation in ABHD12, the gene underlying PHARC, in a family clinically diagnosed with Usher syndrome type 3. Orphanet J Rare Dis. 2012;7:59.

[41] Fu Q, Xu M, Chen X, Sheng X, Yuan Z, Liu Y, et al CEP78 is mutated in a distinct type of Usher syndrome. J Med Genet. 2017;54:190-5.

[42] Namburi P, Ratnapriya R, Khateb S, Lazar CH, Kinarty $\mathrm{Y}$, Obolensky A, et al Bi-allelic Truncating Mutations in CEP78, Encoding Centrosomal Protein 78, Cause Cone-Rod Degeneration with Sensorineural Hearing Loss. Am J Hum Genet. 2016;99:1222-3.

[43] Nikopoulos K, Farinelli P, Giangreco B, Tsika C, Royer-Bertrand B, Mbefo MK, et al Mutations in CEP78 Cause Cone-Rod Dystrophy and Hearing Loss Associated with Primary-Cilia Defects. Am J Hum Genet. 2016;99:770-6.

[44] Khateb S, Zelinger L, Mizrahi-Meissonnier L, Ayuso C, Koenekoop RK, Laxer U, et al A homozygous nonsense CEP250 mutation combined with a heterozygous nonsense C2orf71 mutation is associated with atypical Usher syndrome. J Med Genet. 2014;51:460-9.

[45] Fuster-Garcia C, Garcia-Garcia G, Jaijo T, Fornes N, Ayuso C, Fernandez-Burriel $M$, et al High-throughput sequencing for the molecular diagnosis of Usher syndrome reveals 42 novel mutations and consolidates CEP250 as Usher-like disease causative. Sci Rep. 2018;8:17113.

[46] Kubota D, Gocho K, Kikuchi S, Akeo K, Miura M, Yamaki $\mathrm{K}$, et al CEP250 mutations associated with mild cone-rod dystrophy and sensorineural hearing loss in a Japanese family. Ophthalmic Genet. 2018;39:500-7.

[47] Di Donato N, Neuhann T, Kahlert AK, Klink B, Hackmann K, Neuhann I, et al Mutations in EXOSC2 are associated with a novel syndrome characterised by retinitis pigmentosa, progressive hearing loss, premature ageing, short stature, mild intellectual disability and distinctive gestalt. J Med Genet. 2016;53:419-25.

[48] Carss KJ, Arno G, Erwood M, Stephens J, Sanchis-Juan A, Hull S, et al Comprehensive Rare Variant Analysis via Whole-Genome Sequencing to Determine the Molecular Pathology of Inherited Retinal Disease. Am J Hum Genet. 2017;100:75-90.

[49] Luscan R, Mechaussier S, Paul A, Tian G, Gerard X, Defoort-Dellhemmes $S$, et al Mutations in TUBB4B Cause a Distinctive Sensorineural Disease. Am J Hum Genet. 2017;101:1006-12.

[50] Zito I, Downes SM, Patel RJ, Cheetham ME, Ebenezer ND, Jenkins SA, et al RPGR mutation associated with retinitis pigmentosa, impaired hearing, and sinorespiratory infections. J Med Genet. 2003;40:609-15.

[51] Mansergh FC, Millington-Ward S, Kennan A, Kiang AS, Humphries M, Farrar GJ, et al Retinitis pigmentosa and progressive sensorineural hearing loss caused by a C12258A mutation in the mitochondrial MTTS2 gene. Am J Hum Genet. 1999;64:971-85.

[52] Tracewska-Siemiatkowska A, Haer-Wigman L, Bosch DGM,
Nickerson D, Bamshad MJ, Mendelian G, et al An Expanded Multi-Organ Disease Phenotype Associated with Mutations in YARS. Genes. 2017;8.

[53] Williams KB, Brigatti KW, Puffenberger EG, Gonzaga-Jauregui C, Griffin LB, Martinez ED, et al Homozygosity for a mutation affecting the catalytic domain of tyrosyl-tRNA synthetase (YARS) causes multisystem disease. Hum Mol Genet. 2019;28:525-38.

[54] Boycott KM, Innes AM. When One Diagnosis Is Not Enough. N Engl J Med. 2017;376:83-5.

[55] Ebermann I, Walger M, Scholl HP, Charbel Issa P, Luke C, Nurnberg G, et al Truncating mutation of the DFNB59 gene causes cochlear hearing impairment and central vestibular dysfunction. Human Mutat. 2007;28:571-7.

[56] Errera MH, Robson AG, Wong T, Hykin PG, Pal B, Sagoo MS, et al Unilateral pigmentary retinopathy: a retrospective case series. Acta Ophthalmol. 2019;97:e601-17.

[57] Grosse SD, Ross DS, Dollard SC. Congenital cytomegalovirus (CMV) infection as a cause of permanent bilateral hearing loss: a quantitative assessment. J Clin Virol. 2008;41:57-62.

[58] Morton CC, Nance WE. Newborn hearing screening - a silent revolution. N Engl J Med. 2006;354:2151-64.

[59] Fuster-Garcia C, Garcia-Garcia G, Jaijo T, Blanco-Kelly F, Tian $\mathrm{L}$, Hakonarson $\mathrm{H}$, et al Expanding the Genetic Landscape of Usher-Like Phenotypes. Investig Ophthalmol Vis Sci. 2019;60:4701-10.

[60] Maguire CA, Corey DP. Viral vectors for gene delivery to the inner ear. Hear Res. 2020;394:107927.

[61] Williams DS, Chadha A, Hazim R, Gibbs D. Gene therapy approaches for prevention of retinal degeneration in Usher syndrome. Gene Ther. 2017;24:68-71.

[62] Geleoc GGS, El-Amraoui A. Disease mechanisms and gene therapy for Usher syndrome. Hear Res. 2020;394:107932.

[63] Tornabene P, Trapani I, Minopoli R, Centrulo M, Lupo M, de Simone $S$, et al Intein-mediated protein trans-splicing expands adeno-associated virus transfer capacity in the retina. Sci Transl Med. 2019;11.

[64] Pendse ND, Lamas V, Pawlyk BS, Maeder ML, Chen ZY, Pierce EA, Liu Q. In Vivo Assessment of Potential Therapeutic Approaches for USH2A-Associated Diseases. Adv Exp Med Biol. 2019;1185:91-6.

[65] Fry LE, Peddle CF, Barnard AR, McClements ME, MacLaren RE. RNA editing as a therapeutic approach for retinal gene therapy requiring long coding sequences. Int J Mol Sci. 2020;21.

[66] Hashimoto T, Gibbs D, Lillo C, Azarian SM, Legacki E, Zhang $X M$, et al Lentiviral gene replacement therapy of retinas in a mouse model for Usher syndrome type 1B. Gene Ther. 2007;14:584-94.

[67] Pan B, Askew C, Galvin A, Heman-Ackah S, Asai Y, Indzhykulian $A A$, et al Gene therapy restores auditory and vestibular function in a mouse model of Usher syndrome type 1c. Nat Biotechnol. 2017;35:264-72.

[68] Dulon D, Papal S, Patni P, Cortese M, Vincent PF, Tertrais $M$, et al Clarin-1 gene transfer rescues auditory synaptopathy in model of Usher syndrome. J Clin Invest. 2018;128:3382-401.

[69] Lentz JJ, Jodelka FM, Hinrich AJ, McCaffrey KE, Farris HE, Spalitta MJ, et al Rescue of hearing and vestibular function by antisense oligonucleotides in a mouse model of human deafness. Nat Med. 2013;19:345-50. 
[70] Slijkerman RW, Vache C, Dona M, Garcia-Garcia G, Claustres $M$, Hetterschijt L, et al Antisense Oligonucleotide-based Splice Correction for USH2A-associated Retinal Degeneration Caused by a Frequent Deep-intronic Mutation. Mol Ther Nucleic Acids. 2016;5:e381.

[71] Alagramam KN, Gopal SR, Geng R, Chen DH, Nemet I, Lee R, et al A small molecule mitigates hearing loss in a mouse model of Usher syndrome III. Nat Chem Biol. 2016;12:444-51.

[72] Gopal SR, Lee YT, Stepanyan R, McDermott BM Jr, Alagramam $\mathrm{KN}$. Unconventional secretory pathway activation restores hair cell mechanotransduction in an USH3A model. Proc Natl Acad Sci USA. 2019;116:11000-9.
Hanno J. Bolz

Senckenberg Centre for Human Genetics, Weismüllerstr. 50, 60314

Frankfurt am Main, Germany

h.bolz@senckenberg-humangenetik.de 